\title{
An uncoupling protein 3 gene polymorphism associated with a lower risk of developing Type II diabetes and with atherogenic lipid profile in a French cohort
}

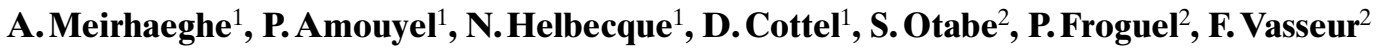 \\ ${ }^{1}$ Department of Epidemiology and Public Health - INSERM U.508, Pasteur Institute of Lille, Central Hospital and University of \\ Lille (CHRU), Lille, France \\ ${ }^{2}$ Institute of Biology of Lille, CNRS UPRES A 8090, Central Hospital and University of Lille (CHRU), Lille, France
}

\section{Abstract}

Aims/hypothesis. The UCP2-UCP3 gene region has been previously associated with obesity and diabetes. In a large representative cohort of Northern France (MONICA project), we studied the effect of a recently reported $\mathrm{C} / \mathrm{T}$ polymorphism located in the $5^{\prime}$ sequences of the UCP3 gene on anthropometric measurements and lipid profile. We also examined the association of this polymorphism with obesity and Type II (non-insulin-dependent) diabetes mellitus.

Methods. The $-55 \mathrm{C} / \mathrm{T}$ polymorphism of the $U C P 3$ gene has been genotyped in 1155 subjects from the MONICA project. Association studies were done with diabetes, obesity and related phenotypes. Results were ascertained in a second cohort of well-characterized Type II diabetic and control subjects.

Results. The variant $\mathrm{T}$ allele was associated with a de- creased risk of developing Type II diabetes. Frequencies of the T allele were $13.3 \%$ compared with $22 \%$, $p=0.04$, in the diabetic and control groups, respectively. This observation was confirmed in the second cohort of French Type II diabetic $(n=171)$ and control $(n=124)$ subjects: $17.8 \%$ compared with $25 \%$, $p=0.03$. Moreover, subjects bearing the $T T$ genotype had higher plasma total cholesterol and LDL-cholesterol concentrations $(p=0.0006$ and $p=0.001$, respectively) than subjects bearing wild or heterozygous genotypes.

Conclusion/interpretation. The UCP3 $-55 \mathrm{C} / \mathrm{T}$ polymorphism was associated with a higher atherogenic profile and modified the risk for the development of Type II diabetes. [Diabetologia (2000) 43: 1424-1428]

Keywords Uncoupling protein (UCP), polymorphism, Type II diabetes, obesity.
Uncoupling proteins (UCPs) constitute a family of intramitochondrial transmembrane carrier proteins [1]. They function to dissipate proton gradients and to uncouple respiration from oxidative phosphorylation, thus converting fuel to heat. Confined to brown adipose tissue $U C P 1$ is unlikely to play a major part in energy expenditure in humans [2]. The UCP2

Received: 25 April 2000 and in revised form: 25 July 2000

Corresponding author: P. Amouyel, Service d'Epidémiologie et de Santé Publique - INSERM U.508, Institut Pasteur de Lille, CHRU, 1 rue Calmette, BP 245, 59019 Lille Cedex, France

Abbreviations: UCP: Uncoupling protein, QTL: quantitative trait locus, PPAR: peroxisome proliferator-activated receptor, HOMA: homeostasis model assessment. gene is widely expressed, especially in skeletal muscle and white adipose tissue [3], whereas $U C P 3$ is predominantly expressed in skeletal muscle, a tissue contributing to thermogenesis in humans $[4,5]$. The $U C P 3$ gene is located within $7 \mathrm{~kb}$ of $U C P 2$ on the human chromosome 11q13 [6]. Both are candidate genes for the regulation of human energy metabolism and thus obesity. Genetic markers close to the $U C P 2 /$ $U C P 3$ locus are linked to resting metabolic rate (RMR) in humans [7], reinforcing the previous hypothesis. Moreover, quantitative trait loci (QTL) linked to obesity and Type II (non-insulin-dependent) diabetes mellitus have been described on the mouse region of chromosome 7 syntenic to human $11 \mathrm{q} 13[8,9]$. An association between polymorphisms of the UCP3 gene and Type II diabetes has been described in a French morbidly obese cohort [10]. Vari- 
Table 1. Genotype and allele distributions of the $U C P 3-55 \mathrm{C} / \mathrm{T}$ polymorphism in the MONICA cohort

\begin{tabular}{llll}
\hline & Non-obese non diabetic subjects & Obese subjects & Type II diabetic subjects \\
\hline$n$ & 894 & 232 & 49 \\
Age (years) & $51 \pm 8$ & $53 \pm 8$ & $56 \pm 7$ \\
Men, \% & 52 & 45 & 47 \\
BMI, kg/m & $24.6 \pm 2.9$ & $34.4 \pm 4.0$ & $31.5 \pm 6.6$ \\
range & $16-29$ & $30-57$ & $21-57$ \\
Glucose, $\mathrm{mmol} / \mathrm{l}$ & $5.25 \pm 0.89$ & $6.44 \pm 2.40$ & $9.36 \pm 3.40$ \\
Insulin, $\mu \mathrm{U} / \mathrm{ml}$ & $13.78 \pm 8.05$ & $24.59 \pm 14.77$ & $23.26 \pm 11.26$ \\
$C C, n(\%)$ & $542(60.6)$ & $143(61.6)$ & $36(73.5)$ \\
$C T, n(\%)$ & $312(34.9)$ & $78(33.6)$ & $13(26.5)$ \\
$T T, n(\%)$ & $40(4.5)$ & $11(4.8)$ & $0(0)^{\mathrm{a}}$ \\
Callele, $n(\%)$ & $1396(78.0)$ & $364(78.4)$ & $85(86.7)$ \\
Tallele, $n(\%)$ & $392(22.0)$ & $100(21.6)$ & $13(13.3)^{\mathrm{b}}$ \\
\hline
\end{tabular}

a Type II diabetic vs control subjects $p=0.12$ (Fisher exact test).

b Type II diabetic vs control subjects, $p=0.04\left(\chi^{2}=4.13\right)$

ations of the UCP3 gene expression have been reported in patients with Type II diabetes, suggesting a potential causal role of the $U C P 3$ gene in this complex trait [11-13]. A C/T polymorphism in the UCP3 gene, located at position -55 according to the beginning of exon 1 [14] is associated with an increase in $U C P 3$ mRNA expression in male non-diabetic Pima Indians [15]. Therefore, we tested the effect of this polymorphism on obesity, lipid variables and Type II diabetes in two independent cohorts: 1155 subjects from the MONICA cohort representative of Northern France and a Type II diabetes case-control study (171 patients/124 control subjects) whose participants were selected from a well-characterized collection of French subjects [16].

\section{Subjects and methods}

The first cohort studied was selected between 1995 and 1997 from a large representative French sample who were aged 35 to 65 years and participated in the risk factor surveys of the WHO-MONICA project (World Health Organization Multinational monitoring of trends and determinants of cardiovascular diseases) [17-19]. The ethics committee of the Central Hospital and University of Lille approved the study. Each subject signed a form giving informed consent. A total of 1155 DNA samples could be obtained. From this sample, 232 subjects were obese $\left(\mathrm{BMI}>30 \mathrm{~kg} / \mathrm{m}^{2}\right), 49$ suffered from Type II diabetes, identified on the basis of a medical diagnosis and on the existence of a specific treatment and 894 were neither diabetic nor obese. To avoid possible interferences of treatments on blood variables, we excluded subjects receiving medical treatment for diabetes, hypercholesterolaemia or hypertension from the statistical analyses, resulting in a sample size of 834 subjects (116 obese and 718 non-obese subjects).

For case-control studies, unrelated Type II diabetic $\left(n=171\right.$, age $=56 \pm 7$ years, $\left.\mathrm{BMI}=28.1 \pm 4.8 \mathrm{~kg} / \mathrm{m}^{2}\right)$ and control subjects $(n=124$, age $=54 \pm 7$ years, BMI $=23.1 \pm 2.4 \mathrm{~kg}$ / $\mathrm{m}^{2}$ ) subjects aged from 35 to 65 years were selected from a well-described French collection [16]. Genomic DNA was extracted from leucocytes as described previously [20]. Typing of the $U C P 3-55 \mathrm{C} / \mathrm{T}$ was achieved as described previously [14]. Insulin resistance (IR) was assessed with the homeostasis model assessment (HOMA) [21]. Statistical analyses were done with the SAS statistical software, version 6.12 (SAS Institute, Cary, N.C., USA). Genotype and allele distributions were compared with Pearson chi-squared or Fisher exact tests. The effect of the polymorphism on the disease was tested in a multiple logistic regression model adjusted for age, sex, body mass index and estimated by the odds ratio, an approximation of the relative risk in case-control studies. The effect of the polymorphism on quantitative variables was tested with a multivariate analysis of covariance using a general linear model. Data for triglycerides, insulin, and glucose were log-transformed to normalize the distributions. Interactions between genotypes and covariates were tested. We considered differences significant at $p$ less than 0.05 .

\section{Results}

In non-obese, non-diabetic subjects $(n=894), 60.6 \%$ were $C C, 34.9 \%$ were $C T$ and $4.5 \%$ were $T T$ (Table 1$)$. The $-55 \mathrm{~T}$ allele frequency was $22 \%$ and the genotype distribution did not statistically significantly differ from the Hardy-Weinberg equilibrium expectation. Allele frequencies were similar in the obese subjects $\left(n=232, \quad \mathrm{BMI}>30 \mathrm{~kg} / \mathrm{m}^{2}\right.$, mean $\mathrm{BMI}=34.4 \pm 4.0 \mathrm{~kg} / \mathrm{m}^{2}$, T allele frequency $=21.6 \%$ ). The $\mathrm{T}$ allele was, however, less frequent in the Type II diabetic subjects $\left(n=49, \mathrm{BMI}=31.5 \pm 6.6 \mathrm{~kg} / \mathrm{m}^{2}\right)$ than in the non-obese, non-diabetic control subjects: $13.3 \%$ compared with $22.0 \%, p=0.04$. We then explored the quantitative effect of the UCP3 C/T polymorphism on the variation of body mass index and lipid variables in subjects without any treatment for diabetes, hypercholesterolaemia or hypertension $\left(n=834, \quad \mathrm{BMI}=25.5 \pm 4.3 \mathrm{~kg} / \mathrm{m}^{2}\right) \quad$ (Table 2). The genotype and allele distributions of the $\mathrm{C} / \mathrm{T}$ polymorphism did not differ from those reported for non-obese, non-diabetic subjects. Homozygote TT subjects had higher plasma cholesterol $(\sim+10 \%$, $p=0.0006)$, LDL-cholesterol $(\sim+18 \%, p=0.001)$ and apolipoprotein concentrations $(\sim+14 \%$, $p=0.0001)$ than $\mathrm{C}$ allele carriers. This effect was con- 
Table 2. Effect of the $U C P 3-55 \mathrm{C} / \mathrm{T}$ polymorphism in the MONICA cohort

\begin{tabular}{|c|c|c|c|c|}
\hline & $C C$ & $C T$ & $T T$ & $p(C C+C T$ vs $T T)$ \\
\hline$n$ & 518 & 281 & 35 & \\
\hline $\mathrm{BMI}, \mathrm{kg} / \mathrm{m}^{2 \mathrm{a}}$ & $25.8 \pm 4.4$ & $25.5 \pm 4.7$ & $25.7 \pm 3.7$ & 0.91 \\
\hline Glucose, $\mathrm{mmol} / \mathrm{l}^{\mathrm{b}}$ & $5.25 \pm 0.78$ & $5.23 \pm 1.04$ & $5.28 \pm 1.00$ & 0.34 \\
\hline \multirow[t]{2}{*}{ Triglycerides, $\mathrm{mmol} / \mathrm{l}^{\mathrm{b}}$} & 1.09 & 1.10 & 1.10 & 0.65 \\
\hline & $(0.63-1.90)$ & $(0.60-2.03)$ & $(0.71-1.72)$ & \\
\hline Cholesterol, $\mathrm{mmol} / \mathrm{l}^{\mathrm{b}}$ & $5.83 \pm 1.03$ & $5.74 \pm 1.00$ & $6.39 \pm 1.15$ & 0.0006 \\
\hline LDL chol., $\mathrm{mmol} / \mathrm{l}^{\mathrm{b}}$ & $3.74 \pm 0.98$ & $3.62 \pm 0.97$ & $4.38 \pm 1.16$ & 0.0011 \\
\hline Apo B, $g / 1^{b}$ & $1.18 \pm 0.28$ & $1.16 \pm 0.29$ & $1.33 \pm 0.33$ & 0.0001 \\
\hline
\end{tabular}

Data are means \pm SD. ${ }^{a} p$ value adjusted for age, sex, alcohol and smoking consumption. ${ }^{\mathrm{b}} p$ values adjusted for age, sex, body mass index, alcohol and smoking consumption. Apo = apolipoprotein, $\mathrm{chol}=$ cholesterol

Table 3. Genotype and allele distributions of the $U C P 3-55 \mathrm{C} /$ $\mathrm{T}$ polymorphism in the Type II diabetes case-control study

\begin{tabular}{lll}
\hline & $\begin{array}{l}\text { Control subjects } \\
(n=124)\end{array}$ & $\begin{array}{l}\text { Type II diabetic subjects } \\
(n=171)\end{array}$ \\
\hline Age (years) & \multicolumn{1}{c}{$54 \pm 7$} & \multicolumn{1}{c}{$56 \pm 7$} \\
BMI, kg/m ${ }^{2}$ & $23.1 \pm 2.4$ & $28.1 \pm 4.8$ \\
Insulin, $\mu \mathrm{U} / \mathrm{ml}$ & $8.48 \pm 5.43$ & $12.68 \pm 9.84$ \\
Glucose, mmol/l & $5.09 \pm 0.50$ & $10.27 \pm 3.93$ \\
$C C, n(\%)$ & $70(56.5)$ & $116(67.8)$ \\
$C T, n(\%)$ & $46(37.1)$ & $49(28.7)$ \\
$T T, n(\%)$ & $8(6.4)$ & $6(3.5)^{\mathrm{a}}$ \\
C allele, $n(\%)$ & $186(75.0)$ & $281(82.2)$ \\
Tallele, $n(\%)$ & $62(25.0)$ & $61(17.8)^{\mathrm{b}}$ \\
\hline
\end{tabular}

a Type II diabetic vs control subjects, $p=0.11\left(\chi^{2}=4.38\right)$.

b Type II diabetic vs control subjects, $p=0.03\left(\chi^{2}=4.47\right)$.

$\mathrm{OR}=0.50(0.26-0.96), p=0.04$ (adjusted for age, sex and $\mathrm{BMI})$ for $C C$ vs $C T+T T$ subjects

sistent in both sexes (data not shown). In contrast, no differences between the two groups of genotypes could be detected for body mass index, other anthropometric measurements (waist to hip ratio and waist circumference) or for fasting plasma glucose, insulin concentrations and the insulin resistance index (data not shown) as measured by the homeostasis model assessment (HOMA). No statistically significant associations with these phenotypes were detected in the subgroup of obese subjects $(n=116)$.

We analysed the distribution of the $U C P 3 \mathrm{C} / \mathrm{T}$ polymorphism in a French case-control study composed of 171 well-characterized patients suffering from Type II diabetes and 124 control subjects. As in the MONICA cohort, the $-55 \mathrm{~T}$ allele was less frequent in the Type II diabetic than in the control subjects: $17.8 \%$ compared with $25 \%, p=0.03$, odds ratio 0.50 [0.26-0.96], $p=0.038$ for $C C$ compared with $C T+T T$ subjects (adjusted for age, sex, body mass index) (Table 3). No difference between the genotypes was detected for the HOMA insulin resistance index.

\section{Discussion}

Our data support the hypothesis of an association between the $-55 \mathrm{C} / \mathrm{T}$ polymorphism of the $U C P 3$ gene and Type II diabetes in French Caucasians. Importantly, these results were found in two independent cohorts (one representative of the general population from the North of France, the second one with diabetic subjects from all parts of France with a strong family history of diabetes and their spouses as control subjects). We found subjects bearing the $T T$ genotype of the $U C P 3-55 \mathrm{C} / \mathrm{T}$ polymorphism have a lower risk for developing Type II diabetes than others do. Previous reports, although conflicting, suggest an alteration of skeletal muscle $U C P 3$ gene expression in Type II diabetic patients [11-13] suggesting that $U C P 3$ regulation plays a part in the development of this disease. Furthermore, several groups reported that the UCP2-UCP3 locus could be genetically linked to the variation of different quantitative traits associated with diabetes and insulin resistance in animals and in humans: hyperinsulinaemia in mice [3], metabolic rate in young non-diabetic Pima Indians [22] and 2-h insulin concentrations during an oral glucose tolerance test in prediabetic Pima Indians [23]. Increased non-esterified fatty acid concentrations induce a noticeable increase in skeletal muscle $U C P 3$ and not UCP2 gene expression in humans [24] and in rats [25]. If long-term weight loss is associated with a down-regulation of UCP3 in humans [26] in agreement with an increased metabolic efficiency in these conditions [27], UCP3 expression is increased during short-term fasting in human and rodent muscle [28-31], a condition characterized by fatty acid release from body fat stores, due to increased lipolysis [32]. The expression of $U C P 3$ seems to better correlate with fatty acid metabolism than with metabolic efficiency [33]. The increase in UCP3 gene expression could constitute a compensatory mechanism to use NEFA as a fuel during the fasting state. It is noteworthy that the role of UCP3 as a conventional uncoupling protein dissipating energy in heat (like 
UCP1) is questionable [34]. High NEFA concentrations do not affect basal glucose-stimulated insulin secretion [35] but are well known to predispose to insulin resistance $[36,37]$. The $-55 \mathrm{C} / \mathrm{T} U C P 3$ polymorphism has been associated with increased skeletal muscle expression of UCP3 in non-diabetic Pima Indians [15], thus we hypothesize that increased expression of $U C P 3$ from the variant $\mathrm{T}$ allele has a protective effect against insulin resistance through NEFA metabolism. The suppression of NEFA induction of UCP3 expression by hyperinsulinaemia [24] could be considered as one of the elements of a vicious circle in Type II diabetes progression. Unfortunately NEFA concentrations were not available in our cohorts and indirect testing of insulin resistance through the homeostasis model remained insignificant.

Our results suggest an effect of the human UCP3 gene on serum lipid concentrations and the atherogenic profile. It is notable that in the MONICA cohort, subjects carrying the $T T$ genotype had a more atherogenic lipid profile characterized by statistically significant higher plasma total cholesterol, higher LDL-cholesterol and apolipoprotein B concentrations than subjects with other genotypes did. These associations were consistent in men and women, suggesting there was no sex effect of the UCP3 polymorphism. Among the numerous genes involved in lipoprotein metabolism those coding for the peroxisome proliferator-activated receptors (PPARs) and particularly PPAR gamma seem of relevance [38]. The latter is activated by thiazolidinediones [39], reagents known to improve insulin sensitivity, but that could also contribute to dyslipidaemia $[40,41]$. In rat the $U C P 3$ gene expression is enhanced by thiazolidinediones [42] and the human $U C P 3$ gene promoter contains putative peroxisome proliferator responsive elements [43]. The location of the UCP3 C/T polymorphism is still debated: originally mapped near the TATA box in the promoter region $(-55)$, a recently published alternative $U C P 3$ genomic organization [43] locates the variant in the 5' UTR at position +527 . These discrepancies make potential functional studies more problematic. In the recently published organization [43], the $-55 \mathrm{C} / \mathrm{T}$ polymorphism is located $4 \mathrm{bp}$ downstream a putative PPAR responsive element and thus could modify the PPAR responsiveness of the UCP3 gene. This gene could be one of the PPAR gamma targets involved in the modulation of insulin sensitivity and lipid metabolism.

Of note, we previously found that the UCP3 TT homozygous genotype was associated with a higher body mass index in morbidly obese subjects as well as in non-obese control subjects [14]. In the present report, the same UCP3 promoter allele seems to protect against diabetes. This apparent paradoxal effect could be explained by interaction between UCP3 and PPARs. It was recently shown that a reduced PPAR gamma activity was associated with a resis- tance to diet-induced obesity in mice [44] as well as with Type II diabetes in humans [45]. In contrast, weight gain is a frequent side effect of thiazolidinediones. If UCP3 is a major PPAR target, it could be speculated that an increase in $U C P 3$ promoter activity could also protect against diabetes while mildly contributing to fat accumulation, which corresponds to our past and current finding.

We do not exclude the $-55 \mathrm{C} / \mathrm{T}$ polymorphism being in linkage disequilibrium with another functional mutation in the UCP2-UCP3 gene cluster. Association between $U C P 2$ polymorphisms and Type II diabetes was recently shown in the very insulin resistant Indian cohort [46]. Altogether, our present data reinforces previous studies suggesting a putative role of this locus on chromosome $11 \mathrm{q}$ in the genetic risk for the metabolic syndrome.

Acknowledgements. We thank V. Codron and X. Hermant for technical assistance. A. Meirhaeghe was supported by a grant from the Foundation for Medical Research. S. Otabe was supported by grants from the French Nord Pas de Calais Regional Council. The WHO-MONICA population study developed in the North of France was supported by grants from the French Nord-Pas de Calais Regional Council, the French Foundation for Medical Research, ONIVINS, the Parke-Davis Company, the Mutuelle Générale de l'Education Nationale (MGEN) which is a health insurance organisation, the French Public Health National Network, the French General Direction of Public Health (DGS), the National Institute of Health and Medical Research (INSERM), the Pasteur Institute of Lille and the Evaluation Unit of the Central Hospital and University of Lille (CHRU).

\section{References}

1. Klaus S, Casteilla L, Bouillaud F, Ricquier D (1991) The uncoupling protein UCP: a membraneous mitochondrial ion carrier exclusively expressed in brown adipose tissue. Int J Biochem 23: 791-801

2. Garruti G, Ricquier D (1992) Analysis of uncoupling protein and its mRNA in adipose tissue deposits of adult humans. Int J Obes Relat Metab Disord 16: 383-390

3. Fleury C, Neverova M, Collins S et al. (1997) Uncoupling protein-2: a novel gene linked to obesity and hyperinsulinemia. Nat Genet 15: 269-272

4. Boss O, Samec S, Paoloni GA et al. (1997) Uncoupling protein-3: a new member of the mitochondrial carrier family with tissue-specific expression. FEBS Lett 408: 39-42

5. Vidal-Puig A, Solanes G, Grujic D, Flier JS, Lowell BB (1997) UCP3: an uncoupling protein homologue expressed preferentially and abundantly in skeletal muscle and brown adipose tissue. Biochem Biophys Res Commun 235: 79-82

6. Pecqueur C, Cassard-Doulcier AM, Raimbault S et al. (1999) Functional organization of the human uncoupling protein-2 gene, and juxtaposition to the uncoupling protein-3 gene. Biochem Biophys Res Commun 255: 40-46

7. Bouchard C, Pérusse L, Chagnon YC, Warden C, Ricquier D (1997) Linkage between markers in the vicinity of the uncoupling protein 2 gene and resting metabolic rate in humans. Hum Mol Genet 6: 1887-1889

8. Warden CH, Fisler JS, Shoemaker SM et al. (1995) Identification of four chromosomal loci determining obesity in a multifactorial mouse model. J Clin Invest 95: 1545-1552 
9. Taylor BA, Phillips SJ (1996) Detection of obesity QTLs on mouse chromosomes 1 and 7 by selective DNA pooling. Genomics 34: 389-398

10. Otabe S, Clement K, Dubois S et al. (1999) Mutation screening and association studies of the human UCP 3 gene in normoglycemic and diabetic morbidly obese patients. Diabetes 48: 206-208

11. Bao S, Kennedy A, Wojciechowski B et al. (1998) Expression of mRNAs encoding uncoupling proteins in human skeletal muscle: effects of obesity and diabetes. Diabetes 47: 1935-1940

12. Krook A, Digby J, O'Rahilly S, Zierath JR, Wallberg-Henriksson $\mathrm{H}$ (1998) Uncoupling protein 3 is reduced in skeletal muscle of NIDDM patients. Diabetes 47: 1528-1531

13. Vidal H, Langin D, Andreelli F et al. (1999) Lack of skeletal muscle uncoupling protein 2 and 3 mRNA induction during fasting in type-2 diabetic subjects. Am J Physiol 277: E830-E837

14. Otabe S, Clement K, Dina C et al. (2000) A Genetic Variation in the 5' flanking region of the UCP3 Gene is Associated with Body Mass Index in Human in Interaction with Physical Activity. Diabetologia 43: 245-249

15. Schrauwen P, Xia J, Walder K, Snitker S, Ravussin E (1999) A novel polymorphism in the proximal UCP3 promoter region: effect on skeletal muscle UCP3 mRNA expression and obesity in male non-diabetic Pima Indians. Int J Obes Relat Metab Disord 23: 1242-1245

16. Hani EH, Hager J, Philippi A et al. (1997) Mapping NIDDM susceptibility loci in French families: studies with markers in the region of NIDDM1 on chromosome $2 \mathrm{q}$. Diabetes 46: $1225-1226$

17. (1988) Geographical variation in the major risk factors of coronary heart disease in men and women aged 35-64 years. The WHO MONICA Project. World Health Stat Q 41: 115-140

18. Tunstall-Pedoe H, Kuulasmaa K, Amouyel P et al. (1994) Myocardial infarction and coronary deaths in the World Health Organization MONICA Project. Registration procedures, event rates, and case-fatality rates in 38 populations from 21 countries in four continents. Circulation 90: 583-612

19. Cottel D, Dallongeville J, Marécaux N et al. (1997) Coronary heart disease risk factor clustering among three French regions: the WHO-MONICA population study. Atherosclerosis 134: 155

20. Miller SA, Dykes DD, Polesky HF (1988) A simple salting out procedure for extracting DNA from human nucleated cells. Nucleic Acids Res 16: 1215

21. Matthews DR, Hosker JP, Rudenski AS et al. (1985) Homeostasis model assessment: insulin resistance and beta-cell function from fasting plasma glucose and insulin concentrations in man. Diabetologia 28: 412-419

22. Walder K, Norman RA, Hanson RL et al. (1998) Association between uncoupling protein polymorphisms (UCP2-UCP3) and energy metabolism/obesity in Pima indians. Hum Mol Genet 7: 1431-1435

23. Pratley RE, Thompson DB, Prochazka M et al. (1998) An autosomal genomic scan for loci linked to prediabetic phenotypes in Pima Indians. J Clin Invest 101: 1757-1764

24. Khalfallah Y, Fages S, Laville M, Langin D, Vidal H (2000) Regulation of uncoupling protein-2 and uncoupling protein3 mRNA expression during lipid infusion in human skeletal muscle and subcutaneous adipose tissue. Diabetes 49: 25-31

25. Weigle DS, Selfridge LE, Schwartz MW et al. (1998) Elevated free fatty acids induce uncoupling protein 3 expression in muscle: a potential explanation for the effect of fasting. Diabetes 47: 298-302

26. Vidal-Puig A, Rosenbaum M, Considine RC et al. (1999) Effects of obesity and stable weight reduction on UCP2 and UCP3 gene expression in humans. Obes Res 7: 133-140

27. Esterbauer H, Oberkofler H, Dallinger G et al. (1999) Uncoupling protein-3 gene expression: reduced skeletal muscle
mRNA in obese humans during pronounced weight loss. Diabetologia 42: 302-309

28. Millet L, Vidal H, Andreelli F et al. (1997) Increased uncoupling protein-2 and -3 mRNA expression during fasting in obese and lean humans. J Clin Invest 100: 2665-2670

29. Samec S, Seydoux J, Dulloo AG (1998) Role of UCP homologues in skeletal muscles and brown adipose tissue: mediators of thermogenesis or regulators of lipids as fuel substrate? FASEB J 12: 715-724

30. Hwang CS, Lane MD (1999) Up-regulation of uncoupling protein-3 by fatty acid in $\mathrm{C} 2 \mathrm{C} 12$ myotubes. Biochem Biophys Res Commun 258: 464-469

31. Giacobino JP (1999) Effects of dietary deprivation, obesity and exercise on UCP3 mRNA levels. Int J Obes Relat Metab Disord 23 [Suppl 6]: S60-S63

32. Stich V, Harant I, De Glisezinski I et al. (1997) Adipose tissue lipolysis and hormone-sensitive lipase expression during verylow-calorie diet in obese female identical twins. J Clin Endocrinol Metab 82: 739-744

33. Berger A, Brand M, O'Rahilly S (1998) Uncoupling proteins: the unravelling of obesity? Increased understanding of mechanisms may lead, in time, to better drugs. BMJ 317: 1607-1608

34. Chung WK, Luke A, Cooper RS et al. (1999) Genetic and physiologic analysis of the role of uncoupling protein 3 in human energy homeostasis. Diabetes 48: 1890-1895

35. Amery CM, Round RA, Smith JM, Nattrass M (2000) Elevation of plasma fatty acids by ten-hour intralipid infusion has no effect on basal or glucose-stimulated insulin secretion in normal man. Metabolism 49: 450-454

36. Jensen MD (1998) Diet effects on fatty acid metabolism in lean and obese humans. Am J Clin Nutr 67: 531S-534S

37. Mokuda O, Sakamoto Y (1999) Peripheral insulin sensitivity is decreased by elevated non-esterified fatty acid level in dexamethasone-treated rats. Diabetes Nutr Metab 12: 252-255

38. Knoblauch H, Busjahn A, Muller-Myhsok B et al. (1999) Peroxisome proliferator-activated receptor gamma gene locus is related to body mass index and lipid values in healthy nonobese subjects. Arterioscler Thromb Vasc Biol 19: 2940-2944

39. Auwerx J, Schoonjans K, Fruchart JC, Staels B (1996) Regulation of triglyceride metabolism by PPARs: fibrates and thiazolidinediones have distinct effects. J Atheroscler Thromb 3: 81-89

40. Raskin P, Rappaport EB, Cole ST et al. (2000) Rosiglitazone short-term monotherapy lowers fasting and post-prandial glucose in patients with Type II diabetes. Diabetologia 43: 278-284

41. Wolffenbuttel BH, Gomis R, Squatrito S, Jones NP, Patwardhan RN (2000) Addition of low-dose rosiglitazone to sulphonylurea therapy improves glycaemic control in Type II diabetic patients. Diabet Med 17: 40-47

42. Kelly LJ, Vicario PP, Thompson GM et al. (1998) Peroxisome proliferator-activated receptors gamma and alpha mediate in vivo regulation of uncoupling protein (UCP-1, UCP-2, UCP3) gene expression. Endocrinology 139: 4920-4927

43. Acin A, Rodriguez M, Rique H et al. (1999) Cloning and characterization of the 5' flanking region of the human uncoupling protein 3 (UCP3) gene. Biochem Biophys Res Commun 258: 278-283

44. Kubota N, Terauchi Y, Miki H et al. (1999) PPAR gamma mediates high-fat diet-induced adipocyte hypertrophy and insulin resistance. Mol Cell 4: 597-609

45. Barroso I, Gurnell M, Crowley VE et al. (1999) Dominant negative mutations in human PPARgamma associated with severe insulin resistance, diabetes mellitus and hypertension. Nature 402: 880-883

46. Cassell PG, Neverova M, Janmohamed S et al. (1999) An uncoupling protein 2 gene variant is associated with a raised body mass index but not Type II diabetes. Diabetologia 42: 688-692 